\title{
Chapter 1 \\ Migration, Urbanity and Cosmopolitanism in a Globalized World: An Introduction
}

\author{
Catherine Lejeune, Delphine Pagès-El Karoui, Camille Schmoll, \\ and Hélène Thiollet
}

Globalization and migration have generated acute and often contradictory changes: they have increased social diversity while inducing global homogenization; they have sharpened differentiation of spaces and statuses while accelerating and amplifying communication and circulations; they have induced more complex social stratification while enriching individual and collective identities. These changes happen to be strikingly visible in cities. Urban contexts, indeed, offer privileged sites of inquiry to understanding the social dynamics of globalization, informal belonging and local citizenships, transient and multi-layered identities, symbolic orders and exclusionary practices. But cities are also material sites and they create multisensorial scapes that shape experiences of globalization and social change. They operate through multiple scales, connecting horizontal extensions and vertical layers of the city with generic, landmark, interstitial and neglected places. Far from being mere contexts, cities are both changing and being changed by migration and globalization.

\footnotetext{
C. Lejeune $(\bowtie)$

LARCA, Université de Paris, Paris, France

D. Pagès-El Karoui

CERMOM, Institut National des Langues et Civilisations Orientales, IC Migrations, Paris, France

C. Schmoll

Géographie-Cités, École des Hautes Études and Sciences Sociales, IC Migrations,

Paris, France

H. Thiollet

CNRS CERI, Sciences Po, IC Migrations, Paris, France

e-mail: helene.thiollet@sciencespo.fr
} 
This book chooses cosmopolitanism as a crucial notion to study migration and mobility in contemporary cities. Central to debates in the early 1990s debates to describe the changes induced by the second modernity, cosmopolitanism was later reframed, recast, and criticized for its ambivalence and political loading, for its Western centrism, uprootedness and theoretical biases. We claim that it is the very "thickness" of the notion that makes it useful. Cosmopolitanism is both a normative and empirical notion which is made up of layers of methodological and theoretical controversies. The discussion on cosmopolitanism took an empirical turn in the early 2010s with ethnographic studies of cosmopolitan encounters, identities, practices and sites, leading David Harvey to speak of a "proliferation of hyphenatedcosmopolitanisms" and "counter-cosmopolitanisms" (Harvey 2009: 1) Building upon these controversies, this book uses the lens of cosmopolitan as a way to explore and make sense of urban diversity and migrant belonging in the global era.

While engaging with renewed empirical debates about cosmopolitanism, this book takes another turn, the urban turn, as a way to further specify the notion of cosmopolitanism and ground the discussion. Building upon empirical research and qualitative methods, we take stock of the varieties of cosmopolitanisms and urbanities in a globalized world. We do so by combining cases from the Global North and Global South at a time when most research on cosmopolitan urbanism have only looked at Northern contexts (Binnie et al. 2006). By doing so, we address a gap in both urban and migration research: while the urban frame is the obvious context of cosmopolitanism and the polis its philosophical and political grounding, the articulation between the two has been overlooked. In the literature on cosmopolitanism, cities have been mostly considered as a décor of cosmopolitan interactions. Conversely, urban scholarship has merely used cosmopolitanism as one descriptive category among others in an attempt to refer to specific forms of urban diversity connected to international migrations. Authors in this book shed new light on core notions in urban studies (global cities and mid-size cities, social and spatial stratification, gentrification, segregation, urban politics, public spaces, city branding) as well as migration and mobility studies (diversity, class-based mobilities, local incorporation and ethnic businesses).

In this book we propose to conceptualize cosmopolitanism as a series of tensions:

- The tension between material or legal configurations and social change or agency. This tension is nailed at the macro and micro levels, looking at historical changes and also daily negotiations with order and authority in their pragmatic and concrete forms.

- The tension between social hierarchies (inequalities) and emancipation. This tension is observed in how migrants and non-migrants use cosmopolitan situations and contexts.

- The tension between differentiation/exclusion and inclusion/belonging. By broadening perspectives, cosmopolitanism can precisely address this tension, which anyway needs to be situated in specific enclaves or sites and at specific moments. 
- The tension between conflict and cooperation. The "cosmopolitan coexistence" of migrants and non-migrants can therefore be studied through sets of conflictual and cooperative social interactions over time and space.

\subsection{Cities and Urbanity}

The city has long been central in the study of social interactions, cooperation and conflicts, as a site of social reproduction and change. Conceptualized by early sociological work (Simmel 1908; Wirth 1938), urban ways of life and "urbanism" should be understood as specific set of practices, skills and values (urbanities). Simmel, for instance, talked about the archetype of the Stranger as a trader with a specific function in the urban ecosystem, a particular position in urban society and a specific identity. The archetype embodies the city's tension between distance and proximity, which is central to understanding cosmopolitanism and lived diversity (Schmoll forthcoming, Pagès-El Karoui forthcoming). Today, migrant traders and shopkeepers are still central figures in urban cosmopolitanism, as discussed in the chapters by Akoka et al. for shops in Nicosia (Cyprus) and Fournet Guérin for Maputo and Antananarivo. As Montesquieu already argued in the eighteenth century, commerce may act as an agent of pacification at the global level - and this liberal paradigm can also apply at the city level through interpersonal relations. Commercial relations function as symbolic exchanges between migrants and nonmigrants and among migrants (Ma Mung 2006; Tarrius 2000). They induce new forms of cosmopolitanism as shown in the case of North African traders in the French city of Marseilles (Peraldi 2001) or Naples (Schmoll 2011).

Social geographers also characterize cities as places of density and diversity (Levy 1997). Richard Sennett explains that the sociological tradition of the Chicago School equates urbanity with cosmopolitanism, the urban condition being defined as a specific way to deal with alterity and diversity (Sennett 2002, 43). A recent debate was fueled notably by sociologist Saskia Sassen's use of "cityness" to designate urban ways of life in a globalized world instead of "urbanity," which, she argued, is charged with a Western sense of cosmopolitanism of what public space is or should be (Sassen 2005). Other work echoes the idea that urbanity is far too ethnocentric as a concept and anchored in Western contexts and histories (Parnell and Oldfield 2014). In turn, we argue that the term "urbanity" can be used in a critical and polycentric perspective as long as it is connected to empirical case studies that are positioned in various spaces and contexts. We adopt Julie-Anne Boudreau's definition as she builds on a century of urban research from Wirth to Bourdieu: "urbanity is a historically situated and unevenly distributed condition which influences lifestyles, modes of interactions, and collective and individual logics of action, no matter where one lives" (Boudreau 2015). We focus on the complex entanglements between urbanity and circulation. Urbanity thus describes the 
interplay between spatial configurations and social practices, identities and representations, an interplay which is geared towards circulation between worlds. It expands practices and representations beyond the city itself, notably through transnational networks. The city, on the one hand, is organized as a site of differentiation through architecture and socio-political regulations that separate classes, genders, races and ethnicities, etc. Urbanity, on the other hand, temporarily counterbalances social differentiation and distancing (Moraes Netto 2017; see Semi in this volume). Such definitions therefore address urbanity both as a condition and as an experience. As urbanity renewed urban research in early sociological work and provided a framework to rethink modernity in the twentieth century, we reckon that cosmopolitanism as urbanity generates a fruitful paradigm to understand contemporary world transformations at the global level.

\subsection{Cosmopolitanisms}

Cosmopolitanism stands out as a radical political project that travelled from political philosophy to social theory. Interest for the notion was renewed by the social, cultural, political and economic changes of the modern globalized era in the 1990s: cosmopolitanism was reframed as the normative project of a "second modernity" (Beck 1996, 2016). Recently, it has become an object of study in empirical research under the auspices of new anthropological research (Werbner 2008). Used, overused and misused across disciplines and times, its semantic trajectory has gone from fame to shame, summits to downfalls. More importantly, cosmopolitanism sometimes even eschews proper definition (Breckenridge et al. 2002, 1-14) and therefore fails to actually describe and characterize cosmopolitan subjects and contexts. Despite this blurriness, cosmopolitanism has generated a great wealth of social science literature and, alongside other key notions like nationalism, citizenship, and sovereignty, has shaped the sociological imagination of scholars. Research is strongly polarized between extremely theoretical endeavors (based on abstract and normative reasoning from philosophy to social theory) and empirically grounded studies focusing on one or several case studies. This polarization prevents us from thinking the complexity of cosmopolitanism in the making and processes of social changes in the global era.

From its Greek philosophical roots to social theory, cosmopolitanism has changed with time, spanning a multitude of meanings that may even be contradictory at times. Cosmopolitanism involves both normative concerns, pragmatic accounts of social interactions and empirical descriptions of spaces, sites and places. However, with its focus on militant concerns for democratic theory, it has sometimes lost sight of the lives, lifestyles, practices, interactions, tastes, places and spaces dwelled and claimed by "cosmopolitan subjects." As a political project enshrining rights and duties, cosmopolitanism, it is fair to say, has failed to become a reference point for contemporary political systems or in national and international discourses still dominated by methodological nationalism and state sovereignty. 
If cosmopolitanism was intensely discussed in the 1990s, it has now lost momentum in the research agendas, findings and rhetoric of contemporary empirical social science. It is absent from the discourse of political leaders and practitioners of social fields in a presumably cosmopolitan world made up of global cities, diasporic networks, transnational social fields, diverse neighborhoods. Indeed, Kant and the Enlightenment tradition equate cosmopolitanism with a "utopian horizon" of humanist values and tolerance opposing the narrow perspectives of nationally-based identities and rights. The international dimension of cosmopolitanism tends to be understood, by Beck, for instance, as a means to subvert the sovereign order and bind nation-states rather than as a ground for a perpetual peace in a hierarchical world order, as Kant foresaw it (Beck 2002; Brown 2009). This early tradition, however, remains quite foreign to the discussion on diversity within nation states or cities. Kant simply equates domestic cosmopolitanism with some sort of legal indifference to otherness (the rule of law applied to all regardless of their nationality/citizenship). As such, the cosmopolitan claim has been considered mostly as a move away from a state-centric perspective on social and political dynamics and a way to shun methodological nationalism (Beck 2007).

Cosmopolitanism in its plural forms is embedded within complex "geometries of power" (Massey 1999). In recent postcolonial and gender perspectives, cosmopolitanism acquired an ambivalent meaning, moving away from the moral projects of Enlightenment theorists and its political implementations. Cosmopolitanism bears a primarily cultural meaning (Pollock et al. 2002, Appadurai 1996), referring to hybrid cultures that emerge from colonial empires. It remains connected to relations of domination in colonial orders and their aftermath, and cosmopolitan cultures and practices are part and parcel of the postcolonial condition. Reminding researchers of the prevalence of power relations even within cosmopolitan contexts and situations certainly shatters the fantasy of a universalist morality. Postcolonial writers certainly changed the meaning of cosmopolitanism: dynamics of cultural hybridization and practices of mobility are always embedded in hierarchies of race, gender, class, etc.

Pnina Werbner has criticized the class bias of cosmopolitanism, its failure to address the diversity of classes, groups and hierarchies within cosmopolitan encounters and configurations (Werbner 1999; see also Calhoun 2002; Schiller et al. 2011; Vertovec and Cohen 2002). The cosmopolis of the "frequent traveler" and that of the transnational "helot" (Cohen 1988) are worlds apart. The spaces and characteristics of "their" cosmopolitan experience, their cosmopolitan subjectivity, cover radically diverse traits. Cosmopolitanism, we argue alongside these authors, should unveil and reflect upon the hierarchies and power relations of the globalized world, together with its hybridity and fluidity. Cosmopolitans are described along the class-based differentiation between mobile transnational elites (Ong 1999) or managerial elites enacting the habitus of a translocal (hyper)bourgeoisie and working-class migrants enacting their "working class or vernacular cosmopolitanisms" (Werbner 1999, 2006), forming the two "global" classes identified by Saskia Sassen (2001). The middle class, however, has received far less attention, and this book certainly fills a gap in this regard (see Lejeune, Pagès-El Karoui, Poulot, Semi in this volume). This 
critique also applies for race, gender and generational differentiation in access to space, culture, recognition and identity, bringing intersectionality into the scientific and political debates.

This book questions the relationship between mobility and cosmopolitanization in times of increasing circulations. Beck pointed at travelers and migrants as major protagonists of processes of cosmopolitanization (2002). However, whether the intensification of mobility and circulation is producing more cosmopolitanism in cities still needs to be proven. In this book we show that the relationship between mobility and cosmopolitanism is ambivalent and complex. Exiles stranded in border cities (like the one described by Michel Agier, Chap. 13, in this volume) may be more cosmopolitan than the global elite circulating between generic places (as described by Jan Duyvendak and Melissa Ley-Cervantes) or city makers (as described by Semi).

Authors in this book vary in their use of the notion of cosmopolitanism: according to contexts and disciplines it can be loaded with political and normative dimensions or merely descriptive. It can refer solely to international migrants and asylum seekers (Agier, Thiollet and Assaf, Pagès el-Karoui, Schmoll Clochard Akoka and Polyzou, Fournet-Guérin), migrant youths and descendants of migrants (Lejeune) or also to internal migrants or non-migrants (Mermier, Chap. 5, Fouquet, Chap. 4, Poulot, Chap. 9, Fournet-Guérin, Chap. 7, in this book) and travelers (Semi, Duyvendak and Ley-Cervantes). In some chapters, cosmopolitanism is an etic concept used by researchers and others, an emic category employed by actors such as urban planners and architects in Giovanni Semi's chapter. Some authors engage with the debates on the variety of cosmopolitanisms and the critiques of the concept, others use it with more caution and resort to other notions such as conviviality, diversity, belonging and acts of citizenship (Duyvendak and Ley-Cervantes, Le Bail and Lieber, Semi, Lejeune). In the course of this book, the notion is therefore contested, challenged and put to the test of variegated empirical and epistemic contexts.

\subsection{Situating Cosmopolitanisms}

Although often mentioned, the spatial and/or local dimension of the "cosmopolitan situation" is often barely conceptualized or discussed as such. In the wake of David Harvey's call for the analysis of the conditions for the emergence of cosmopolitanisms in their historical and geographical contexts (Harvey 2009), some geographers have emphasized the eminently geographical dimension of cosmopolitanism (Yeoh 2004), a tendency used with greater frequency in recent years (see Poulot and Fournet-Guérin in this volume). Such a stance implies looking at specific local situations of encounters, such as coffee places and streets (see chapters from Akoka et al. and Duyvendak and Ley-Cervantes). The book thus pays particular attention to the sites of interaction, the canopies theorized by Elijah Anderson (2012), to capture cosmopolitanism as a process (Beck 2016). 
As such, this book investigates the role of the city in cosmopolitanism by documenting cosmopolitan practices in the city and focusing on situated versions of cosmopolitanisms. It interrogates what the city does to cosmopolitanism and what cosmopolitanism does to the city. Researching cosmopolitanism, then, requires investigating the meaning of places that are constantly negotiated, debated, questioned. Rather than branding some specific cities or sites as more cosmopolitan than others, our intent is to contextualize cosmopolitanism as urbanity in space and time.

Across space, the book thus offers comparisons between various scales and spatial levels: global cities and smaller towns, neighborhoods, streets, refugee camps, borders, and airports in various world regions (Africa, Europe, North America, Middle East), therefore overcoming the usual Western approach to cosmopolitanism. This approach breaks with the usual empirical divide between cities in the North and South (Robinson 2002). This comparative and descriptive approach echoes other studies that have engaged with diversity in specific contexts (Glick Schiller and Çağlar 2011).

Across time, the authors in this volume adopt a diachronic take on cosmopolitan interactions: they study daytime street life and the urban nightlife, workplaces and waiting spaces, hotels and coffee places in between travels, family life and the home, picnic areas and shopping malls, etc. The chapters also pay attention to the historical dynamics of urban settings, architecture, and the material configurations of urbanity. They consider the history of migration, citizenship and mobility regimes to embed the local variations of cosmopolitanism within historical contexts.

Urbanity can thus be conceptualized fully, not only as geographically and historically situated but also as a momentary experience of transcending differences: as such, urbanity urges us to look at moments of ordinary life, such as the differentiation between day and night (see Fouquet, Chap. 4, in this book), or at the making of temporary situations, such as urban interstices (see Akoka et al., Chap. 8, in this book).

By comparing spaces and moments, histories and sites, we contribute to theoretical debates opened up by urban ethnographers and migration researchers who have sought to characterize cosmopolitanism and diversity (Vertovec 2007; Wessendorf 2013). Several notions are used to analyze the cosmopolitan dynamics and practices, such as the cosmopolitan situation (Rinaudo and Hily 2003), rooted (Appiah 2006), circumstantial (Berthomière 2003), ordinary (Lamont and Aksartova 2002), everyday (Schmoll 2003), vernacular (Pollock et al. 2002, Werbner 1999), tactical cosmopolitanism, wounded (Rose 2015) and subaltern cosmopolitanism (Zeng 2014). Building upon these more specific notions, the various chapters explore the tensions mentioned above between structure and agency, hierarchies and emancipation, inclusion and exclusion, conflict and cooperation. They thus bring pluralistic views on a cosmopolitanism of practices and encounters embodied in contacts and trajectories, emotions and positions anchored in the spatial dimension of social and power relations of urban settings. 


\subsection{Migrants and (Urban) Change}

Since the 2010s, border policies and migration controls have progressively toughened and the question of migrants' agency has become more stringent. Renewed nationalist discourses and identity politics are also contributing to the increased fragility of some migrants and foreign communities in the Global North and the Global South, both in liberal and illiberal contexts. Local policies, in turn, have a crucial role in the multiscalar governance of migration. Migrant-friendly policies implemented on the local level include contemporary sanctuary cities which promote new forms of citizenship (Isin 2002) or cities of refuge (see Lejeune in this volume). At the other end of the spectrum, local policies may foster segregation and abjection. The positions of cities towards migrants may differ totally from national policies, as shown during the 2015 "refugee crisis" in Europe. Expanding upon the universalist claims of the right to cosmopolitanism formulated by Immanuel Kant, Jacques Derrida introduced the idea of "city of refuge," which enacts the principle of cosmopolitan hospitality in urban settings (Derrida 1997). ${ }^{1}$ His call has been taken extremely seriously by scholars (see Agier, Chap. 13, in this book) and some European mayors - most notably Leoluca Orlando of Palermo in 2015 - who have declared their constituencies "cities of refuge" in the context of the refugee crisis. Cosmopolitan hospitality is thus opposed in the policy making arena to the current wake of nationalism and populism.

In this wider context, migrants are easily turned into objects of migration and integration policies, powerless victims of state policies. A strong trend of contemporary scholarship in migration studies, however, seeks to capture the contribution of migrants to urban and social change and the agency of mobile individuals, regardless of their status (Mainwaring 2016).

This book fits in this literature and acknowledges that migrants are actors in the process of cosmopolitanization or counter-cosmopolitanization (Glick Schiller 2015). It offers a novel take on the agency of migrants and mobile individuals. Their presence and circulation contribute to the production of meanings and feelings for both migrants and non-migrants. Nick Van Hear thus defends the idea that "taking account of migrants' agency, perceptions and aspirations" allows us to link micro-level understanding of migration to macro-level trends in development and globalisation (Van Hear 2010). We contend that despite structurally unequal settings, migrants and even refugees can contribute to social change, even if their methodological victimization often prevents us from seeing the transformative impact of their presence in both host, transit and origin countries. They do so through everyday and subtle forms of participation, production and even

\footnotetext{
${ }^{1}$ The Kantian definition of hospitality as "a moral and legal relation which hold among individuals across bounded communities" (Benhabib 2004) was used as a way to limit "the law of world citizenship to conditions of universal hospitality." Kant's definition was, at the time, extremely narrow, as it concerned merely a right to be treated "neutrally" (not a right to residency or belonging), and it did not apply to groups and races considered unworthy of the ethical acknowledgement.
} 
subversion in workplaces (Scheibelhofer 2019) and private and public places (see Thiollet and Assaf, Chap. 12, in this book).

Glick Schiller and Caglar (2011) also showed that migrants and mobile agents participate in the scaling and re-scaling of cities. They contribute to changing the image of the city towards the outside world via international ranking, reputation and branding (see Mermier, Chap. 5, Pagès-El Karoui, Chap. 6, Poulot, Chap. 9, and Semi, Chap. 3, in this book). They reshape representations of cities from within via gentrification or impoverishment, via multiculturalization or segregation (see Lebail and Lieber, Chap. 10, in this book). This perspective moves away from cities as segregated spaces where interactions are entirely controlled through spatial partitions, a view that needs rethinking given the fluidity of urban changes and the changing dynamics of differentiation. They also move away from the idea that cosmopolitanization and its correlate changes are necessarily framed as positive. The figure of the migrant inducing social change does not leave aside the structural social, political and economic domination migrants suffer under. It also does not underplay the complex feelings of otherness or differential belonging that migrant experiences carry and their subjective alienation in national and local contexts (as Michel Agier investigates in his chapter). In fact, at various scales, the access to rights, the limited agency and the systems of domination and exploitation of migrants co-exist with regimes of privileges, those of the highly mobile elites and transient bourgeoisies who benefit from unlimited access to spaces. Political and economic inequalities across classes, ethnicities, nationalities, gender and age shape urban interactions but also the feelings and experiences of place, as shown for bourgeois travelers (see the chapter by Duyvendak and Ley-Cervantes) or for urban designers (see the chapter by Semi). Such unequal cosmopolitan conditions are embodied and play out in the urban field in a variety of ways, according to material, spatial, symbolic, bodily, and timely contexts.

To concretely illustrate this theoretical stance, this book pays particular attention to consumption practices both in their substantial, spatial and ideational dimension: what do migrants and non-migrants consume? how and where do they consume it? what narratives or feelings are attached to consumption? Consumption involves key experiences of belonging or alienation, integration, hybridization or differentiation. As such, it works as an entry point to investigating the role of migrants in city changes, illustrating, for instance, how cities of production have become cities of consumption (Germann Molz 2011; Zukin 1998). In globalization studies, consumption is often referred to as a key indicator in assessing theories of cultural convergence, differentiation or hybridization: consuming global goods and frequenting generic places mean greater cosmopolitan feelings or a greater willingness to engage with diversity and the other (Hannerz 1990). On the contrary, ethnic consumption (and ethnic economies) would lead to fragmentation of cultures, social practices and relations of production (Fischer and Massey 2000). In between, some see signs of global hybridization and mixing in consumption. This book does not adhere to clear-cut views on consumption but rather explores the varieties of meanings and processes it carries which induce incremental changes for interactions, representations and material spaces. As such, consumption seems to rather operate 
as one of the many factors of social and urban change, intersecting with other processes such as gentrification, suburbanization, and touristification, which is thus combined with dynamics of intersectional differentiation. Such a view builds upon previous research that showed how business directed to ethnic groups radically change the landscape and sensescapes of cities (Rhys-Taylor 2013).

The chapters of this book thus engage with the complexity of consumption practices and the variety of meanings consumption can acquire for migrants and nonmigrants. Shopping malls built around the world display an immense variety of goods and stage cosmopolitan consumption even when societies remain extremely segregated and exclusionary (see the chapters by Pagès-El Karoui and Thiollet and Assaf). For buyers, strategies of consumption reflect the ambiguities of individual and collective identities: integrating into globalization, maintaining ethnic distinction, claiming cultural roots, adhering to local tastes, etc. In Cyprus, Mozambique, Madagascar or Québec, street-level consumption reveals contradictory cultural and social dynamics (see Akoka et al., Chap. 8, and Fournet-Guérin, Chap. 7, in this book) which are instrumentalized by local authorities for city branding and propaganda (see Poulot, Chap. 9, in this book). Cosmopolitanism has also been used in the Middle East and the Gulf since the 2000s as a form of nation branding (see Mermier, Chap. 5, and Pages El Karoui, Chap. 6, in this book). The book looks at the plurality of contexts in which the term is in use and branded in link with consumption in order to question cosmopolitanization at a time when illiberal migration regimes enforce increasingly exclusionary regulations.

Beyond consumption, none of the practices we observe at the city level are devoid of political meaning even if they seem to be depoliticized. Some of the authors in this book find that these practices contribute to what we could call a moral economy of cosmopolitanism as urbanity (see Thiollet and Assaf, Chap. 12, in this book). Following Didier Fassin, we define moral economy as "the production, distribution, circulation, and use of moral sentiments, emotions and values, and norms and obligations in social space" $(2009,37)$. Everyday urban habits and policies jointly and iteratively define urban moral regimes, deciding who deserves to be empowered or attracted in/by the city, and, conversely, who does not deserve to have access to the city or some of its spaces (see Lebail and Lieber, Chap. 10, Pagès el-Karoui, Chap. 6 , in this book). They also rule on migrants' visibility: who is entitled to be seen and who should remain invisible in public spaces like working class migrant men in the Gulf countries (se Pagès el-Karoui, Chap. 6, Thiollet and Assaf, Chap. 12, in this book) or chinese sex workers in Paris (Le Bail and Lieber, Chap. 10, in this book). Finally, they induce differential feelings and senses of self, of belonging or of alienation that translate into discourses and behaviors, as in the case of the global elite in Madrid (Duyvendak and Ley-Cervantes, Chap. 2, in this book) or urban youth in Dakar at night (Fouquet in this volume). These feelings and practices delineate the moral boundaries of everyday life alongside legal and official prescriptions. The empirical descriptions provided in each chapter thus contribute to a rich discussion on cosmopolitanism that stems from everyday practices, material configurations and emotions at the city level. 


\section{References}

Anderson, E. (2012). The cosmopolitan canopy race and civility in everyday life. New York: Norton.

Appadurai, A. (1996). Modernity at large: Cultural dimensions of globalization. Minneapolis: University of Minnesota Press.

Appiah, A. (2006). Cosmopolitanism: Ethics in a world of strangers. New York: Norton.

Beck, U. (1996). World risk society as cosmopolitan society?: Ecological questions in a framework of manufactured uncertainties. Theory, Culture \& Society, 13(4), 1-32.

Beck, U. (2002). The cosmopolitan society and its enemies. Theory, Culture \& Society, 19(1-2), 17-44.

Beck, U. (2007). The cosmopolitan condition: Why methodological nationalism fails. Theory, Culture \& Society, 24(7-8), 286-290.

Beck, U. (2016). Varieties of second modernity and the cosmopolitan vision. Theory, Culture \& Society, 33(7-8), 257-270.

Berthomière, W. (2003). L'émergence d'une Tel-Aviv cosmopolite ou les effets d'un fin mélange entre reconfigurations sociopolitiques internes et externes. Cahiers de la Méditerranée, 67, 299-312.

Benhabib, S. (2004). The rights of others: Aliens, residents and citizens. Cambridge. New York: Cambridge University Press.

Binnie, J., Holloway, J., Millington, S., \& Young, C. (2006). Cosmopolitan Urbanism. London: Routledge.

Boudreau, A-J. (2015). Urbanity as a way of life. In S. Vincent-Geslin, H. Adly, Y. Zorro, \& Y. Pedrazzini (Eds.), Translating the city: Interdisciplinarity in urban studies (pp. 141-161). Oxford: EPFL Press.

Breckenridge, C. A., Pollock, S., Bhabha, H., \& Chakrabarty, D. (Eds.). (2002). Cosmopolitanism. Durham: Duke University Press.

Brown, G. W. (2009). Grounding cosmopolitanism: From Kant to the idea of a cosmopolitan constitution. Edinburgh: Edinburgh University Press.

Calhoun, C. (2002). The class consciousness of frequent travellers: Towards a critique of actually existing cosmopolitanism. In S. Vertovec, \& R. Cohen (Eds.), Conceiving cosmopolitanism: Theory, context and practice (pp. 86-109). New York: Oxford University Press.

Cohen, R. (1988). The new helots: Migrants in the international division of labour. Aldershot: Gower.

Derrida, J. (1997). Cosmopolites de Tous Les Pays, Encore Un Effort! Paris: Galilée.

Fassin, D. (2009). Moral economies revisited. Annales. Histoire, Sciences Sociales, 64(6), $1237-1266$.

Fischer, M. J., \& Massey, D. S. (2000). Residential segregation and ethnic enterprise in U.S. Metropolitan Areas. Social Problems, 47(3), 408-424.

Germann Molz, J. (2011). Cosmopolitanism and consumption. In M. Rovisco \& M. Nowicka (Eds.), The Ashgate research companion to cosmopolitanism (pp. 33-52). London: Routledge.

Glick Schiller, N. (2015). Diasporic cosmopolitanism: Migrants, sociabilities and city-making. In N. Glick Schiller \& A. Irving (Eds.), Whose cosmopolitanism?: Critical perspectives, relationalities and discontents (pp. 103-120). Oxford: Berghahn Books.

Glick Schiller, N., \& Çağlar, A. (Eds.). (2011). Locating migration: rescaling cities and migrants. Ithaca: Cornell University Press.

Hannerz, U. (1990). Cosmopolitans and locals in world culture. Theory, Culture \& Society, 7(2-3), 237-251.

Harvey, D. (2009). The banality of geographical evils. In Cosmopolitanism and the geographies of freedom (pp. 98-122). New York: Columbia University Press.

Isin, E. (2002). Being political: Genealogies of citizenship. Minneapolis: University of Minnesota Press.

Lamont, M., \& Aksartova, S. (2002). Ordinary cosmopolitanisms: Strategies for bridging racial boundaries among working-class men. Theory, Culture \& Society, 19(4), 1-25. 
Levy, J. (1997). Penser La Ville: Un Imperatif Sous Toutes Les Latitudes. CEMOTI, 24. https://doi. org/10.4000/cemoti.1458.

Ma Mung, E. (2006). Négociations identitaires marchandes. Revue Européenne des Migrations Internationales, 22(2), 83-93.

Mainwaring, $\dot{C}$. (2016). Migrant agency: Negotiating Borders and migration controls. Migration Studies, 4(3), 289-308. https://doi.org/10.1093/migration/mnw013.

Massey, D. (1999). Imagining globalization: Power-geometries of time-space. In A. Brah, M. J. Hickman, \& M. M. an Ghaill (Eds.), Global futures (pp. 27-44). London: Palgrave Macmillan.

Moraes Netto, V. (2017). The social fabric of cities. Abingdon: Routledge.

Ong, A. (1999). Flexible citizenship: The cultural logics of transnationality. Durham: Duke University Press.

Pagès-El Karoui, D. (Forthcoming). Cosmopolitan cities. In V. Cicchelli \& S. Mesure (Eds.), On cosmopolitanism in hard times. Leiden: Brill.

Parnell, S., \& Oldfield, S. (Eds.). (2014). The Routledge handbook on cities of the global south. London: Routledge.

Peraldi, M. (Ed.). (2001). Cabas et Containers: Activités Marchandes Informelles et Réseaux Migrants Transfrontaliers. Paris: Maisonneuve et Larose.

Pollock, S., Bhabha, H. K., Breckenridge, C. A., \& Chakrabarty, D. (2002). Cosmopolitanisms. In S. Pollock, H. K. Bhabha, C. A. Breckenridge, \& D. Chakrabarty (Eds.), Cosmopolitanism (pp. 1-14). Duke University Press.

Rhys-Taylor, A. (2013). The essences of multiculture: A sensory exploration of an inner-city street market. Identities, 20(4), 393-406.

Rinaudo, C., \& Hily, M-A. (2003). Cosmopolitisme et altérité. Les nouveaux migrants dans l'économie informelle. Tsantsa. Revue de la Société Suisse d'Ethnologie / Zeitschrift der Schweizerischen Ethnologischen Gesellschaft / Journal of the Swiss Ethnological Society. Académie suisse des sciences humaines et sociales, Société Suisse d'Ethnologie, pp. 48-57.

Robinson, J. (2002). Global and world cities: A view from off the map. International Journal of Urban and Regional Research, 26(3), 531-554.

Rose, J. (2015). Wounded cosmopolitanism. In N. Glick Schiller \& A. Irving (Eds.), Whose cosmopolitanism?: Critical perspectives, relationalities and discontents (pp. 41-48). Oxford: Berghahn Books.

Sassen, S. (2001). The global city: New York, London, Tokyo (2nd ed.). Princeton: Princeton University Press.

Sassen, S. (2005). Cityness in the urban age. Urban Age Bulletin, 2, 1-3.

Scheibelhofer, E. (2019). Conceptualising the social positioning of refugees reflections on socioinstitutional contexts and agency with a focus on work. Identities, 26(3), 289-304.

Schiller, N. G., Tsypylma, D., \& Gruner-Domic, S. (2011). Defining cosmopolitan sociability in a transnational age. An introduction. Ethnic and Racial Studies, 34(3), 399-418.

Schmoll, C. (2003). Cosmopolitisme au quotidien et circulations commerciales à Naples. Cahiers de La Méditerranée, 67, 345-360.

Schmoll, C. (2011). The making of a transnational marketplace: Naples and the impact of Mediterranean cross-border trade on regional economies. Cambridge Journal of Regions, Economy and Society, 5(2), 221-238.

Schmoll, C. (Forthcoming). International mobility and cosmopolitanism in the global age. In V. Cicchelli \& S. Mesure (Eds.), On cosmopolitanism in hard times. Leiden: Brill.

Sennett, R. (2002). Cosmopolitanism and the social experiences of cities. In Conceiving cosmopolitanism: Theory, context, and practice (pp. 42-47). New York: Oxford University Press.

Simmel, G. (1921 [1908]). The sociological significance of the 'Stranger'. In R. Park, \& E. Burgess (Eds.), Introduction to the science of sociology (pp. 322-327). Chicago: University of Chicago Press.

Tarrius, A. (2000). Les nouveaux cosmopolitismes: Mobilités, identités, territoires. La Tour d'Aigues: Editions de l'Aube. 
Van Hear, N. (2010). Theories of migration and social change. Journal of Ethnic and Migration Studies, 36(10), 1531-1536.

Vertovec, S. (2007). Super-diversity and its implications. Ethnic and Racial Studies, 30(6), $1024-1054$.

Vertovec, S., \& Cohen, R. (Eds.). (2002). Conceiving cosmopolitanism: Theory, context and practice. New York: Oxford University Press.

Werbner, P. (Ed.). (1999). Global pathways. Working class cosmopolitans and the creation of transnational ethnic worlds. Social Anthropology, 7(1), 17-35.

Werbner, P. (Ed.). (2006). Vernacular cosmopolitanism. Theory, Culture \& Society, 23(2-3), 496-498.

Werbner, P. (Ed.). (2008). Anthropology and the new cosmopolitanism: Rooted, feminist and vernacular perspectives. New York: Berg.

Wessendorf, S. (2013). Commonplace diversity and the 'ethos of mixing': Perceptions of difference in a London neighbourhood. Identities, 20(4), 407-422.

Wirth, L. (1938). Urbanism as a way of life. American Journal of Sociology, 44(1), 1-24.

Yeoh, B. S. A. (2004). Cosmopolitanism and its exclusions in Singapore. Urban Studies, 41(12), 2431-2445.

Zeng, M. (2014). Subaltern cosmopolitanism: Concept and approaches. The Sociological Review, 62(1), 137-148.

Zukin, S. (1998). Urban lifestyles: Diversity and standardisation in spaces of consumption. Urban Studies, 35(5-6), 825-839.

Open Access This chapter is licensed under the terms of the Creative Commons Attribution 4.0 International License (http://creativecommons.org/licenses/by/4.0/), which permits use, sharing, adaptation, distribution and reproduction in any medium or format, as long as you give appropriate credit to the original author(s) and the source, provide a link to the Creative Commons license and indicate if changes were made.

The images or other third party material in this chapter are included in the chapter's Creative Commons license, unless indicated otherwise in a credit line to the material. If material is not included in the chapter's Creative Commons license and your intended use is not permitted by statutory regulation or exceeds the permitted use, you will need to obtain permission directly from the copyright holder. 